\title{
UPAYA TEORITIS PENANGGULANGAN \\ KENAKALAN ANAK (JUVENILE DELIQUENCY)
}

Dr. Syahrul Akmal Latif, M.Si. \& M.Zulherawan, S.Sos, M.Soc.Sc.

\begin{abstract}
Current technological developments have had a lot of bad effects on children, causing child delinquency and lately we often hear news about children, both children as victims and as perpetrators of delinquency. To solve the problem of children's delinquency must be done and based on a comprehensive understanding of the causes. So this article aims to discuss the causes of child delinquency from both the theoretical and conceptual perspectives as well as the scope of law and methods for dealing with child delinquency in Indonesia. The problem of juvenile delinquency continues to increase based on data from the KPAI of the Republic of Indonesia showing that there were 11,492 cases of delinquency and violating the law in 2019 so that several approaches are needed to prevent and overcome current juvenile delinquency which is mostly done through a repressive approach so that appropriate methods and approaches to address juvenile delinquency problems must be carried out based on a deep understanding of the causes of juvenile delinquency.
\end{abstract}

Keywords: Juvenile Delinquency, Theoretical, Prevention.

\section{Pendahuluan}

Di zaman yang semakin berkembang semakin beragam pula tingkah laku serta masalah sosial yang terjadi di masyarakat terutama masalah anak. Perkembangan teknologi sekarang ini telah banyak memberi pengaruh buruk bagi anak sehingga menyebabkan terjadinya kenakalan anak. Masa anak merupakan masa dimana seorang individu mengalami peralihan dari satu tahap ke tahap berikutnya dan mengalami perubahan baik emosi, tubuh, minat, pola perilaku, dan juga penuh dengan masalah-masalah (Hurlock, 2011).

Akhir akhir ini sering sekali kita mendengar pemberitaan seputar anak, baik anak sebagai korban maupun sebagai Pelaku kenakalan. 
Masalah kenakalan anak anak dewasa ini semakin dirasakan meresahkan masyarakat, baik di Negara-negara maju maupun Negara-negara yang sedang berkembang. Dalam kaitan ini, masyarakat Indonesia telah mulai pula merasakan keresahan tersebut, terutama mereka yang berdomisili di kota-kota besar.

Sebagai upaya untuk memberikan perlindungan terhadap anak dari berbagai isu yang ada, maka Pemerintah Republik Indonesia telah meratifikasi konvensi hak anak melalui Keputusan Presiden RI Nomor 36 tahun 1990. Dalam konvensi hak anak salah satunya yang sangat membutuhkan perhatian khusus adalah perlindungan anak yang berkonflik dengan hukum. Dalam hukum nasional perlindungan khusus bagi anak diatur dalam Undang-Undang Nomor 35 tahun 2014 Tentang Perlindungan Anak dan Undang-Undang Nomor 11 Tahun 2012 Tentang Sistem Peradilan Pidana Anak.

Kenakalan anak adalah perilaku jahat/dursila atau kejahatan/kenakalan anak-anak muda, merupakan gelaja sakit (patologis) secara sosial pada anak-anak dan anak yang disebabkan oleh suatu bentuk pengabdian sosial, sehingga mereka itu mengembangkan bentuk tingkah laku yang menyimpang. Keberadaan anak yang demikan di lingkungan kita memang perlu mendapatkan perlindungan khusus terutama anak yang dijatuhi pidana karena pada hakikatnya anak tidak dapat melindungi dirinya dari berbagai macam tindakan yang menimbulkan kerugian mental, fisik, sosial dalam berbagai kehidupan. Anak harus mendapatkan perlindungan oleh individu, kelompok, organisasi sosial dan pemerintah (Sambas;2013;13).

Jika kita membicarakan anak sebagai pelaku kenakalan, maka Kenakalan tersebut adalah sebagai salah satu bentuk problema sosial dan merupakan sebuah kenyataan yang harus dihadapi oleh setiap lapisan masyarakat. Di Indonesia masalah kenakalan anak/anak dirasa telah mencapai tingkat yang cukup meresahkan bagi masyarakat. Pada masa inilah, para anak anak sering sekali melakukan perbuatan-perbuatan atau tindakan yang menjurus pada 
perbuatan melawan hukum (weder rech telijkheid) dan merugikan pihak lain seperti perkelahian, pencurian, minum minuman keras, narkoba, menghilangkan nyawa seseorang dan lain sebagainya. Kondisi ini memberi dorongan kuat kepada pihak - pihak yang bertanggung jawab mengenai masalah ini, seperti kelompok edukatif di lingkungan sekolah, kelompok hakim dan jaksa di bidang penyuluhan dan penegakan.

\section{Konsep Kenakalan Anak (Juvenile Deliquency)}

Pada umumnya perilaku kenakalan anak dan anak dimaknai sebagai suatu bentuk perilaku yang tidak sesuai dengan norma-norma yang hidup di tengah masyarakat. Perilaku anak yang tidak sesuai dengan norma itu dianggap sebagai anak yang cacat sosial (Kartini Kartono, 2017:93) dan kemudian masyarakat menilai cacat tersebut sebagai sebuah kelainan sehingga perilaku mereka pun disebut dengan kenakalan.

Pengertian kenakalan anak atau juvenile delinquency yang dikemukakan oleh para ilmuwan beragam. Namun pada intinya menyepakati bahwa kenakalan anak merupakan perbuatan atau tingkah laku yang bersifat anti sosial. Sebagaimana juga disepakati oleh badan peradilan Amerika Serikat pada saat pembahasan Undang-Undang Peradilan Anak di negara tersebut (Wagiati Soetodjo, 2008:9).

Kenakalan anak adalah perilaku jahat/dursila atau kejahatan/kenakalan anak-anak muda, merupakan gelaja sakit (patologis) secara sosial pada anak-anak dan anak yang disebabkan oleh suatu bentuk pengabdian sosial, sehingga mereka itu mengembangkan bentuk tingkah laku yang menyimpang. Keberadaan anak yang demikian di lingkungan kita memang perlu mendapatkan perlindungan khusus terutama anak yang dijatuhi pidana karena pada hakikatnya anak tidak dapat melindungi dirinya dari berbagai macam tindakan yang menimbulkan kerugian mental, fisik, sosial dalam berbagai kehidupan. Anak harus mendapatkan perlindungan oleh individu, kelompok, organisasi sosial dan pemerintah (Sambas;2013;13). 




Kenakalan anak (juvenile delinquency), secara etimologis juvenile artinya young, anak-anak, anak muda, ciri karakteristik pada periode anak, sedangkan delinquency artinya doing wrong, kemudian diperluas artinya menjadi jahat, a-sosial, kriminal, pelanggar aturan, pembuat ribut, pengacau penteror, tidak dapat diperbaiki lagi, (Soetodjo, 2006;31).

Selanjutnya menurut Kartono dalam Nasrhiana $(2012,7)$, kenakalan kejahatan atau kenakalan yang dilakukan anak-anak muda merupakan gejala patologi secara sosial pada suatu bentuk pengabdian sosial sehingga mereka mengembangkan bentuk pengabdian tingkah laku menyimpang.

menurut Kartini Kartono (2017;46) a. Delinquency Individual
Delinkuensi individual merupakan bentuk kekalutan mental dalam diri.

Hal ini dikarenakan adanya disintegrasi diri dengan kekacauan batin dan kecenderungan penyimpangan tingkah laku. Hampir seluruh anak delinkuensi individual ini berasal dan besar di lingkungan keluarga yang brutal, diliputi permasalahan keluarga, dan selalu menyia-nyiakan anakanaknya. Sehingga anak yang besar di lingkungan seperti itu tidak mampu menjalin kedekatan emosional dengan orang lain. Sebagai akibatnya anak tidak mempunyai perasaan kemanusiaan dan hati nuraninya sulit diberi peringatan.

\section{b. Delinquency Situasional}

Delinkuensi atau kenakalan jenis ini banyak dipengaruhi oleh stimuli sosial dan tekanan lingkungan sehingga membentuk perilaku buruk pada anak. Kemudian juga kenakalan ini sering dilakukan oleh anak yang normal seperti suka melanggar peraturan, norma sosial dan hukum formal.

c. Delinquency Sistematik 
Delinkuensi sistematik adalah perilaku menyimpang yang telah disistematisir dalam suatu kelompok atau gang dan dibenarkan oleh segenap anggota kelompok atau gang tersebut sehingga kejahatannya menjadi terorganisir atau sistematis.

\section{d. Delinquency Kumulatif}

Delinkuensi jenis ini merupakan konflik budaya kontroversial yang mana terdapat banyak kelompok sosial yang tidak dapat didamaikan karena selalu terlibat dalam persaingan yang didasari oleh rasa dendam dan benci yang sangat mendalam.

Anak yang memiliki gangguan dalam perkembangan, anak yang tidak terpenuhi secara wajar maka anak dapat mengalami berbagai gangguan perilaku sebagai berikut:

1. Gangguan pemusatan perhatian/ hiperaktif $(\mathrm{GPP} / \mathrm{H})$, merupakan gangguan yang perlu perhatian secara khusus, karena : memiliki resiko lebih tinggi untuk mengalami berbagai permasalahan dalam kehidupannya. Anak sulit untuk mematuhi aturan dan tuntutan dari lingkungan seperti tuntutan dari lingkungan sehari-hari dan juga tuntutan pada bidang akademikanya. Anak dapat mempengaruhi rasa keberhargaan diri anak, dan meningkatkan tingkah laku agresif terhadap lingkungan. Adapun gejala utama yang ditunjukan GPP/H, dengan ciri-cirinya antara 6 atau lebih, dan berlangsung selama sekurangkurangnya 6 bulan, sampai pada derajat terjadinya maladaptif atau tidak sesuai dengan tahap perkembangan, sebagai berikut: Inatensi (kurang terfokusnya perhatian). Impulsivitas (kecenderungan bertindak sebelum berfikir). Hiperaktivitas (gerakan yang berlebihan).

2. Gangguan perilaku. Memfokuskan pada perilaku yang melanggar hakhak orang lain dan norma-norma sosial, seperti: agresi dan kekejian terhadap orang, merusak kepemilikan orang lain membakar, berkelahi, berbohong, mencuri, membunuh, menganiaya, membolos sekolah, kabur dari rumah, berperilaku provokatif yang 
menyimpang, dan sikap menentang yang berat dan menetap.

Sedangkan menurut Jensen dalam Sarwono (2012;256), kenakalan anak dapat dibagi menjadi empat jenis, yaitu:

a. Kenakalan yang menimbulkan korban fisik pada orang lain seperti perkelahian, perkosaan, perampokan, dan pembunuhan.

b. Kenakalan yang menimbulkan korban materi seperti: perusakan, pencurian, pencopetan, dan pemerasan.

c. Kenakaan sosial yang tidak menimbulkan korban di pihak orang lain seperti: pelacuran, penyalahgunaan obat-obatan, dan di Indonesia hubungan seks sebelum menikah juga dapat dimasukan kedalam jenis kenakalan anak.

d. Kenakalan yang melawan status, seperti status anak sebagai pelajar dengan cara membolos, mengingkar status orangtua dengan cara minggat atau meninggalkan rumah tanpa izin dan membantah perintah orangtua. Pada usia mereka, perilaku-perilaku mereka memang belum melanggar hukum dalam arti yang sesungguhnya karena yang dilanggar adalah status-status dalam lingkungan primer (keluarga) dan sekunder (sekolah) yang memang tidak diatur oleh hukum secara terinci. Akan tetapi, kalau kelak anak ini dewasa hal ini sangat berpengaruh di dalam lingkungan masyarakat. Karena itulah pelanggaran status ini oleh Jensen digolongkan juga sebagai kenakalan dan bukan sekedar perilaku menyimpang.

Menurut Ali dan Asrori (2012;255), terdapat berbagai faktor yang dapat menyebabkan kenakalan pada anak, yaitu:

\section{Rational Choice}

Teori ini mengutamakan faktor individu dari pada faktor lingkungan. Kenakalan anak yang dilakukannya adalah atas pilihan, interes, motivasi atau kemauannya sendiri. Di Indonesia banyak yang percaya teori ini, misalnya kenakalan anak dianggap sebagai kurang iman sehingga anak dikirim ke pesantren kilat atau dimasukkan ke sekolah agama. Yang lain menganggap anak yang nakal 
kurang disiplin sehingga diberi latihan kemiliteran..

\section{Sosial Disorganization}

Kaum positivisme pada umumnya lebih mengutamakan faktor budaya. Yang menyebabkan kenakalan anak adalah berkurangnya atau menghilangnya pranata masyarakat yang selama ini menjaga keseimbangan atau harmoni dalam masyarakat. Orangtua yang sibuk dan guru yang kelebihan beban merupakan penyebab dari berkurangnya fungsi keluarga dan sekolah sebagai pranata kontrol.

\section{Strain}

Teori ini dikemukakan oleh Merton. Intinya adalah bahwa tekanan yang besar dalam masyarakat, misalnya kemiskinan menyebabkan sebagian dari anggota masyarakat yang memilih jalan rebellion melakukan kejahatan atau kenakalan anak.

\section{Differential Assosiation}

Menurut teori ini, kenakalan anak adalah akibat salah pergaulan. Anak-anak nakal karena bergaul dengan anak yang nakal juga. Paham ini banyak dianut orangtua di Indonesia, yang sering kali melarang anak-anaknya untuk bergaul dengan teman-teman yang dianggap nakal, dan menyuruh anak-anaknya untuk berteman dengan anak-anak yang pandai dan rajin belajar.

\section{Labelling}

Ada pendapat yang mengatakan bahwa anak nakal selalu dianggap atau dicap (diberi label) nakal :

\section{Tabel I.1 Kriteria Kasus Anak yang Melanggar Hukum Tahun 2019}

\begin{tabular}{|c|l|l|}
\hline No. & \multicolumn{1}{|c|}{ Kriteria Kasus } & Jumlah Kasus \\
\hline 1. & NAFZA & 2.820 \\
\hline 2. & Kekerasan fisik dan psikis & 140 \\
\hline 3. & Pornografi dan cyber crime & 3.323 \\
\hline 4. & Traficking dan eksploitasi & 2.156 \\
\hline 5. & Kejahatan seksual & 102 \\
\hline
\end{tabular}

Sumber: KPAI Republik Indonesia, 2019 
Menurut tabel diatas dapat dilihat anak yang melakukan kenakalan dan tindak kejahatan setiap tahun selalu mengalami peningkatan, hal ini pada dasarnya tidak terlepas dari berbagai faktor sosial yang mempengaruhinya. Oleh karena itu dirasakan perlunya dilakukan perlindungan anak oleh berbagai pihak terkait, terutama oleh negara. Menurut data dari KPAI Republik Indonesia menunjukkan bahwa kasus anak nakal dan melanggar hukum pada Tahun 2019 terdapat 11.492 kasus yang berhadapan dengan hukum.

\section{Konsep Kenakalan Anak Dalam} Teoritis

\section{A. Teori Kontrol Sosial}

Teori Kontrol Sosial atau sering disebut Teori Kontrol, berangkat dari asumsi dasar bahwa individu dalam masyarakat mempunyai kecenderungan yang sama kemungkinannya menjadi baik atau jahat. Baik jahatnya seseorang sepenuhnya tergantung pada masyarakatnya. Ia menjadi baik kalau masyarakatnya membuatnya demikian dan menjadi jahat apabila masyarakatnya membuat demikian (John Hagan, Modern Criminology). Pertanyaan dasar yang dilontarkan paham ini berkaitan dengan unsurunsur pencegahan yang mampu menangkal timbulnya perilaku delinkuen (dalam hal ini perilaku jahat) di kalangan anggota masyarakat, utamanya pada anak anak, yaitu: mengapa mereka patuh dan taat pada norma-norma masyarakat? Atau mengapa mereka tidak melakukan perilaku menyimpang? Pertanyaan tersebut mencerminkan bahwa penyimpangan bukan merupakan problematik, yang dipandang sebagai persoalan pokok adalah ketaatan atau kepatuhan pada norma-norma kemasyarakatan.

Dengan demikian menurut paham ini sesuatu yang perlu dicari kejelasan tentang ketaatan seseorang pada norma dan faktor-faktor yang menyebabkan patuh atau taat pada norma-norma kemasyarakatan. Pada dasarnya upaya penjelasan penyimpangan perilaku tidak harus dilakukan dengan cara menjelaskan perilaku tidak patuh norma (Travis Hirschi, Berkeley, 1969). Oleh karena itu, penganut 
paham ini berpendapat bahwa ikatan sosial (social bond) seseorang dengan masyarakatnya dipandang sebagai faktor pencegah timbulnya penyimpangan. Seseorang yang lemah atau terputus ikatan sosialnya dengan masyarakat, dan dapat bebas melakukan penyimpangan. Selanjutnya Travis Hirschi mengklasifikasikan unsur-unsur ikatan sosial itu meliputi: a. Attachment, b. Commitment, $c$. Involvment, dan d. Belief.

1. Attachment, mengacu pada kemampuan seseorang untuk menginternalisasikan norma-norma masyarakat. Kalau seseorang melanggar norma-norma masyarakat, maka berarti ia tidak peduli dengan pandangan serta kepentingan orang lain, berarti ia tidak terikat lagi dengan normanorma masyarakat itu. Orang-orang tersebut tidak terikat lagi dengan masyarakat, tidak peka dengan kepentingan orang lain, sehingga ia akan merasa bebas untuk melakukan penyimpangan.

2. Commitment, mengacu pada perhitungan untung rugi keterlibatan seseorang dalam perbuatan penyimpangan, dimana orang pada umumnya menginventarisasikan segala hal termasuk waktunya, tenaga dirinya sendiri dalam kegiatan di masyarakat, dengan maksud untuk memperoleh reputasi di masyarakat.

3. Involvment, mengacu pada suatu pemikiran bahwa apabila seseorang disibukkan dalam berbagai kegiatan konvensional maka ia tidak akan pernah sempat berpikir apalagi melibatkan diri dalam perbuatan penyimpangan. Seseorang yang terlibat dalam kegiatan konvensional berarti ia terikat dengan segala aspek yang terkandung dalam kegiatan tersebut.

4. Belief, mengacu pada situasi keanekaragaman penghayatan kaidah kemasyarakatan (terutama pada keabsahan moral) di kalangan anggota masyarakat. Para pelaku penyimpangan tersebut umumnya mengetahui bahwa perbuatannya salah, namun makna dan pemahamannya itu kalah bersaing dengan keyakinan lain (kerancuan penghayatan keabsahan moral), sehingga kendor ikatan dirinya 
dengan tertib masyarakat dan pada gilirannya ia merasa bebas untuk melakukan penyimpangan. Dalam kondisi dan situasi kekinian, dimana masyarakat berkembang maka keberadaan ikatan sosial sangat berpeluang untuk menjadi mengendor bahkan terlepas dari ikatan masyarakat, utamanya pada kalangan anak.

\section{B. Teori Subkultur Delinkuen}

Teori ini dapat ditemukan dalam bukunya Albert K. Cohen (1955) yang berjudul Delinkuen Boys, The Culture of The Gang. Fokus perhatiannya terarah pada satu pemahaman bahwa perilaku delinkuen di kalangan usia muda, kelas bawah merupakan cerminan ketidakpuasan terhadap norma-norma dan nilai-nilai kelompok kelas menengah dan mendominasi kultur masyarakat. Karena kondisi sosial yang ada dipandang sebagai kendala upaya mereka untuk mencapai kehidupan sesuai dengan trend yang ada, sehingga mendorong kelompok usia muda kelas bawah mengalami konflik budaya, yang disebut status frustation. Akibatnya, meningkatkan keterlibatan anak-anak kelas bawah itu pada kegiatan geng-geng dan berperilaku menyimpang yang sifatnya "nonutilitarian, nonmaliciaous and nonnegatistics" (Albert K. Cohen, 1955:25).

Para pelaku delinkuen merupakan bentukan sub- budaya terpisah dan memberlakukan sistem tata nilai masyarakat luas. Ia menggambarkan sub-budaya sesuatu yang diambil dari norma-norma budaya yang lebih besar, namun kemudian dibelokkannya secara terbalik dan berlawanan. Perilaku delinkuensi dibenarkan oleh sistem tata nilai budaya mereka, karena perilaku itu dianggap keliru oleh norma-norma budaya yang lebih besar (Albert K. Cohen, 1955:26-27) membuat klasifikasi dari sub-sub budaya delinkuen menjadi:

a. a parent sub-culture - the negativistic subcultur originally identified to delinquent boys;

b. the conflict-oriented sub-culturthe cultur of a large gang that engages in collective violence;

c. the drug addict subcultur - groups of youth whose lives revolve around the purchase sale, use of narcotics; 
d. semi professional theft - youths who engage in the theft or robbery of merchandise for the purpose of later sale and monetary gain; and

e. middle class subcultur - delinquent group that rise, because of the pressures of living in middle class environment.

Lebih lanjut R.A. Cloward dan L.E. Ohlin mengemukakan teori yang disebut Differential Opportunity System. Teori ini mengemukakan bahwa penyimpangan di suatu wilayah perkotaan merupakan fungsi dari perbedaan kesempatan yang dimiliki anak- anak untuk mencapai, baik tujuan yang legal maupun yang ilegal. Manakala kesempatan untuk memperoleh yang legal terblokir maka tindak kriminal pun mungkin terjadi, sehingga kecenderungan keterlibatan pada penggunaan narkotika atau dengan kekerasan juga dapat terjadi. Sub budaya yang mungkin terjadi menurut Cloward dan Ohlin dikelompokkan menjadi 3 (tiga) bentuk yaitu:

1. Criminal Subcultur, bentuk-bentuk perilaku geng yang ditujukan untuk kepentingan pemenuhan uang atau harta benda;

2. Conflict Subcultur, bentuk geng yang berusaha mencari status dengan menggunakan kekerasan;

3. Reatreatist Subcultur, bentuk geng dengan ciri-ciri penarikan diri dari tujuan dan peranan konvensional dan kemudian mencari pelarian dengan menyalahgunakan obat atau narkotika atau sejenisnya.

C. Teori Anomi

Teori Anomi diajukan oleh Robert K. Merton, dimana dalam teorinya mencoba melihat keterkaitan antara tahap-tahap tertentu dari struktur sosial dengan perilaku delinkuen, ia melihat bahwa tahapan tertentu dari struktur sosial akan menumbuhkan suatu kondisi dimana pelanggaran terhadap norma-norma kemasyarakatan merupakan wujud reaksi normal (jadi seolah-olah terjadi keadaan tanpa norma atau anomi).

Dalam teori anomi terdapat dua unsur yang dijadikan perhatian dalam mempelajari berbagai bentuk perilaku delinkuen yaitu unsur struktur sosial dan budaya. Unsur budaya menghasilkan goals yang berarti 
adanya tujuan-tujuan dari kepentingankepentingan yang sudah membudaya, yang meliputi kerangka aspirasi dasar manusia, seperti dorongan untuk hidup. Tujuan tersebut merupakan bentuk kesatuan dan didasari oleh urutan nilai dalam berbagai tingkatan perasaan dan makna. Sedangkan unsur struktural menimbulkan adanya means yang berarti bahwa adanya aturanaturan dan cara-cara kontrol yang melembaga dan diterima sebagai sarana untuk mencapai tujuan yang telah membudaya dalam masyarakat.

D. Teori Belajar

Teori Belajar (Social Learning Theory), dikembangkan oleh Ronald Akkers yang dikaitkan dengan delinkuensi anak. Pendekatannya berpegang pada asumsi, bahwa perilaku seseorang dipengaruhi oleh pengalaman belajar, pengalaman kemasyarakatan disertai nilai-nilai dan penghargaan dalam kehidupan di masyarakat.

Secara umum, teori ini berpandangan bahwa anak-anak akan memperagakan perilakunya atas dasar:

a. reaksi yang diterimanya dari pihak lain (positif atau negatif), b. perilaku orang dewasa yang mempunyai hubungan dekat dengan mereka (utamanya orangtua), c. perilaku yang mereka lihat di TV maupun di bioskop.

Apabila seorang anak mengamati perilaku agresif, misalnya orang dewasa menampar atau memukul orang lain saat bertengkar, dan apabila anak melihat bahwa perilaku agresif diperbolehkan atau mendatangkan hadiah (pujian), akan terjadi kecenderungan anak akan bereaksi dengan cara kekerasan selama ia mengalami kejadian serupa. Akhirnya anak pun akan menguasai teknik-teknik agresifitas dan akan semakin yakin bahwa penggunaan kekerasan itu akan mendatangkan hadiah (pujian). Dampaknya, pengikut teori ini menyatakan seorang anak yang tumbuh kembang dalam lingkungan rumah dimana kekerasan menjadi kebiasaan, maka anak pun akan belajar untuk meyakini bahwa perilaku seperti itu dapat diterima dan mendatangkan hadiah atau pujian (Paulus Hadisuprapto, 2008:78-79). 
Pembahasan

Tingginya angka kenakalan anak yang dilihat dari data KPAI tahun 2019 sehingga perlu penanggulangan kenakalan anak yang lebih baek dan tindak berdampak akan ke dalam kejiwaan anak tersebut yang mana pada awalnya para kriminolog mengasumsikan bahwa unsur-unsur niat dan kesempatan sangat berpengaruh terhadap sebab - sebab timbulnya kejahatan atau kenakalan anak. Hasil dalam Seminar Kriminologi III di Semarang (1976) menyatakan bahwa unsur niat terkait dengan faktor-faktor endogen dan eksogen. Yang dimaksud dengan faktor endogen tersebut adalah faktorfaktor yang berasal dari dalam diri anak itu sendiri yang mempengaruhi tingkah lakunya, antara lain:

a. Cacat yang bersifat biologis dan psikis;

b. Perkembangan kepribadian dan intelegensi yang terhambat sehingga tidak bisa menghayati norma-norma yang berlaku.

Sedangkan faktor-faktor eksogen adalah faktor berasal dari luar diri anak yang dapat mempengaruhi tingkah lakunya. Sedangkan menurut Tannebaum (Giallombardo, 1972), bahwa sebagaimana kejahatan, terjadinya delinkuensi anak itu karena adanya konflik antara suatu kelompok (group) dengan masyarakat (community) yang lebih luas. Oleh karena itu, permasalahan kenakalan anak atau delinkuensi anak bukan hanya disebabkan oleh faktor biologis dan psikologis anak saja. Faktor sosial, khususnya lingkungan pergaulannya (peers group), dapat menjadi salah satu sebab utama terjadinya kenakalan tersebut.

Upaya penanggulangan kenakalan anak memang harus benarbenar dilakukan sedini mungkin, anakanak delinkuen jika tidak ditangani secara benar akan dapat berkembang menjadi penjahat (criminal) pada masa dewasanya. Di lain pihak, kejahatan atau kenakalan anak itu sendiri sangat kompleks, oleh karena itu banyak teori atau pendekatan yang membahas permasalahan kenakalan anak. Dalam perspektif kriminologi, para ahli sering membahasnya melalui pendekatanpendekatan (approaches) biologis, psikologis, dan sosial. Dalam era 
modern saat ini terdapat kecenderungan bahwa faktor lingkungan dapat menjadi salah satu faktor dominan yang menyebabkan terjadinya kenakalan anak. Selain itu, dari faktor lingkungan pula dapat digunakan sebagai salah satu sarana (solusi) dalam upaya penanggulangan kenakalan anak. Lingkungan di mana anak tumbuh dan berkembang sesungguhnya ikut bertanggungjawab dalam upaya menanggulangi kenakalan anak. Dalam perspektif kriminologi banyak teori atau konsep yang dikemukakan dalam rangka mencari solusi upaya menanggulangi kenakalan anak. Pola-pola prevensi, represif, dan kuratif seharusnya diterapkan secara tepat sehingga dapat mencapai hasil yang maksimal.

Berikut pola yang dapat dilakukan dalam upaya penanggulangan masalah kenakalan anak anak

a. Upaya Preventif Upaya pencegahan terjadinya kenakalan anak secara umum.

1. Mengenal dan mengetahui ciri umum dan khas anak
2. Mengetahui kesulitan-kesulitan yang secara umum dialami oleh para anak. Kesulitan-kesulitan manakah yang biasanya menjadi sebab timbulnya penyaluran dalam bentuk kenakalan.

3. Usaha pembinaan anak :

a. Menguatkan sikap mental anak supaya mampu menyelesaikan persoalan yang dihadapinya.

b. Memberikan pendidikan bukan hanya dalam penambahan pengetahuan dan keterampilan melainkan pendidikan mental dan pribadi melalui pengajaran agama, budi pekerti dan etiket.

c. Menyediakan sarana-sarana dan menciptakan suasana yang optimal demi perkembangan pribadi yang wajar.

d. Usaha memperbaiki keadaan lingkungan sekitar, keadaan sosial keluarga maupun masyarakat di mana terjadi banyak kenakalan anak.

Dengan usaha pembinaan yang terarah para anak akan mengembangkan diri dengan baik sehingga keseimbangan diri akan tercapai dimana terciptanya hubungan 
yang serasi antara aspek rasio dan aspek emosi. Pikiran yang sehat akan mengarahkan mereka keperbuatan yang pantas, sopan dan bertanggungjawab yang diperlukan dalam menyelesaikan kesulitan atau persoalan masing-masing.

b. Upaya represif

Usaha menindak pelanggaran norma - norma sosial dan moral dapat dilakukan dengan mengadakan hukuman terhadap setiap perbuatan pelanggarannya.

Pada umumnya tindakan represif diberikan dalam bentuk memberikan peringatan secara lisan maupun tulisan kepada pelajar dan orang tua, melakukan pengawasan khusus oleh kepala sekolah dan team guru atau pembimbing dan melarang bersekolah untuk sementara atau seterusnya tergantung dari macam pelanggaran tata tertib sekolah yang digariskan. Usaha prefentif kenakalan anak dengan cara abolisionistis adalah untuk mengurangi, bahkan untuk menghilangkan sebab-sebab yang mendorong anak melakukan perbuatan - perbuatan delinquen dengan bermotif apa saja. Di samping itu tidak kalah pentingnya usaha untuk memperkecil, bahkan meniadakan faktor- faktor yang membuat anak anak terjerumus ke dalam perbuatan-perbuatan delinquen. Konsep- konsep tersebut diatas memerlukan realisasi dalam kehidupan masyarakat. Dapat dipastikan pelaksanaan prevensi tidak mungkin apabila hanya dilaksanakan oleh masing-masing lembaga secara sendiri-sendiri. Akan tetapi pelaksanaan tersebut memerlukan kerjasama yang erat satu sama lain.

c. Upaya kuratif

Dilakukan setelah tindakan pencegahan lainnya dilaksanakan dan dianggap perlu mengubah tingkah laku si pelanggar anak anak itu dengan memberikan pendidikan. Tindakan-tindakan kuratif bagi usaha penyembuhan anak delinquen juga antara lain berupa:

a. Menghilangkan semua sebabmusabab timbulnya kenakalan anak, baik yang berupa pribadi familiar, sosial dan kultural. 
b. Melakukan perubahan lingkungan dengan jalan mencarikan orang tua angkat/asuh dan memberikan fasilitas yang diperlukan bagi perkembangan jasmani dan rohani yang sehat bagi anak - anak anak.

c. Memindahkan anak - anak ke sekolah yang lebih baik, atau ke tengah lingkungan sosial yang baik.

d. Memberikan tempat latihan bagi para anak untuk hidup teratur, tertib dan berdisiplin.

e. Memanfaatkan waktu senggang di kamar latihan, untuk membiasakan diri bekerja, belajar dan melakukan rekreasi sehat dengan disiplin tinggi.

f. Menggiatkan organisasi pemuda dengan program - program latihan vokasional untuk mempersiapkan anak anak delinquen itu bagi pasaran kerja dan hidup di tengah masyarakat.

g. Mendirikan klinik psikologi untuk meringankan dan memecahkan konflik emosional dan gangguan kejiwaan lainnya.

h. Memberikan pengobatan medis dan terapi psikoanalitis bagi mereka yang mengalami gangguan kejiwaan.

d. Upaya pre-emtif Upaya-upaya awal yang dilakukan dalam penanggulangan kejahatan untuk mencegah terjadinya tindak pidana secara dini. Usaha-usaha yang dilakukan dalam penanggulangan kejahatan secara pre-emtif adalah menanamkan nilainilai atau norma-norma yang baik sehingga norma-norma tersebut terinternalisasi dalam diri seseorang. Kenakalan-kenakalan yang dilakukan oleh anak-anak dan anak seyogiyanya diupayahkan penanggulangan secara sungguhsungguh dalam arti penanggulangan yang setuntas-tuntasnya, upaya ini merupakan aktivitas yang pelik apabila ditinjau secara integral, akan tetapi apabila ditinjau secara terpisah-pisah maka upaya ini merupakan kegiatan yang harus dilakukan secara profesional yang menuntut ketekunan dan berkesinambungan dari suatu kondisi menuju kondisi yang lain.

Kondisi fisik dan sosial lingkungan keluarga dan pergaulan 
anak anak harus diusahakan positif dan kondusif bagi perkembangan jiwa anak anak yang sedang dalam tahap labil atau peralihan dari anak-anak ke dewasa untuk menemukan jati dirinya. Dengan faktor - faktor diatas, diharapkan anak anak bisa menempuh masa-masa sulitnya dengan positif dan berhasil guna bagi kehidupan dewasanya kelak.

Upaya dalam kriminologi dikenal dengan penanggulangan kejahatan yang pada umumnya dan perilaku delikuensi anak pada khususnya dalam hukum pidana dikenal apa yang disebut Kebijakan Kriminal. Usaha rasional masyarakat untuk menanggulangi kejahatan (termasuk perilaku delinkuenasi anak). Kebijakan kriminal dalam gerak langkahnya dapat dilakukan lewat sarana penal (Hukum Pidana) dan sarana non penal (diluar hukum Pidana). Kedua kebijakan tersebut (penal dan non penal) merupakan pasangan yang saling menunjang dalam gerak langkah penanggulangan kejahatan pada umumnya dan perilaku delinkuensi anak pada khususnya dimasyarakat.

$$
\text { Upaya penanggulangan }
$$

kejahatan lewat jalur penal lebih menitik beratkan pada sifat repressive (penindasan/pemberantasan/penumpas an) sesudah kejahatan terjadi, sedangkan jalur non- penal lebih menitik beratkan pada sifat preventive (pencegahan/penangkalan/pengendalia n) sebelum kejahatan terjadi. Selain itu,upaya penanggulangan kenakalan anak secara yuridis harus memperhatikan masalah batasan usia anak nakal tersebut yang dapat bertanggung jawab, serta jenis atau bentuk pemidanaan apa yang paling tepat bagi si anak delinquent (sanksi pidana atau tindakan).

Penanggulangan kenakalan dan kejahatan yang dilakukan oleh anak tentunya berbeda dengan penanggulangan kejahatan yang dilakukan oleh orang dewasa. Karena dalam hal ini anak masih sangat rentan baik secara fisik maupun psikisnya. Asas-asas yang mendasari kebijakan penanggulangan kenakalan anakpun berbeda dengan orang dewasa. Modifikasi langkah - langkah penal maupun non penal dalam politik kriminal bagi kenakalan anak adalah 
bahwa kebutuhan akan keterpaduan (integritas) antara kebijaksanaan penanggulangan kejahatan dengan politik sosial dan politik penegakan hukum. Dalam konteks kebijakan penanggulangan kenakalan anak dan perilaku kenakalan anak, perlu domodifikasi politik kesejahteraan masyarakat dan politik perlingungan masyarakat secara umum. Secara khusus diarahkan pada politik kesejahteraan anak dan politik perlindungan hak-hak anak, baik anak pada umumnya maupun anak yang menjadi korban kejahatan orang dewasa (neglected children) maupun korban anak pelaku kenakalan anak (delinquent children).

\section{Penutup}

Tingginya angka kenakalan anak perlu kita dapati sebab dan dampak yang buruk bagi perkembangan anak sehingga sangat perlu adanya penanggulan kenakalan anak yang baik yang mana dilihat dari berbagai teori-teori di atas dapat dijadikan bahan pertimbangan dalam menanggulangi kejahatan yang dilakukan oleh anak, sehingga latar belakang anak melakukan kejahatan dipahami dengan tepat, untuk diterapkan kebijakan penanggulangan dengan tepat pula. Termasuk dalam upaya penanggulangan kejahatan dengan sarana atau kebijakan non penal serta di sesuai ubah melihat kondisi demografi dan situasi dari anak yang melakukan kejahatan sehingga apa yang menjadi dan dibutuh kan dalam penanggulangan kenakalan anak dapat tercapai.

Selain itu, dalam penanggulangan yang dilakukan secara Upaya Preventif, Upaya represif, Upaya kuratif, Upaya pre-emtif, dan upaya dalam kebijakan kriminal mungkin dapat menjadi suatu mekanisme yang boleh akan membatu dan cara upaya untuk mengatasi kenakalan anak yang dihadapkan dengan banyak persoalan. Kenakalan anak anak adalah salah satu hal yang menyimpang karena ada pikiran negatif dan pengaruh negatif dalam diri anak anak dan disini dukungan dari orang tua, keluarga, teman, dan masyarakat sekitar merupakan salah satu bentuk penguatan anak untuk lebih bertingkah laku positif. Sebab 
musabab dari timbulnya kenakalan anak dan upaya penanggulangannya dapat ditinjau, baik dari perspektif yuridis maupun non yuridis (khususnya kriminologi). Jika kedua perspektif tersebut digunakan secara tepat sesungguhnya akan menunjang Sistem Penanggulangan anak yang bertujuan untuk perbaikan dan pertumbuhan fisik dan psikis yang baik, yang berguna bagi perkembangan pribadi dan sosial anak di kemudian hari. 


\section{Daftar Pustaka}

Ali, M. dan Asrori, M., 2012. Psikologi Remaja: Perkembangan Peserta Didik.Jakarta: PT Bumi Aksara.

Bartolass, Clemens, 1990, Juvenile Deliquency, California: Macmillan Publishing Company.

Cloward, Richard A. dan Lloyn Ohlin, 1960, Delinquency and Opportunity: A Theory of Delinquent Gang, New York.

Cohen, Albert K., 1955, Delinquent Boys, The Cultur of The Gang, New York.

Cunneen, Rob White Chris, 2009, Juvenile Justice: , “Kekerasan terhadap Murid dalam Kasus Youth and Crime in Australia, Oxford: OxfordUniversity Press.

Hadisuprapto, Paulus, 2008, Delikuensi Anak: Pemahaman dan Penanggulangannya, Malang: Bayumedia.

Hirschi, Travis, 1969, Causes of Delinquency, Berkeley.

Hurlock, Elizabeth, B. 2011. Psikologi Perkembangan. Jakarta: Erlangga.

Kartono, Kartini, 2017, Kenakalan Remaja, Patologi Sosial 2, Jakarta: PT. RajaGrafindo Persada.
Kaufman, James M., 1989, Characteristics of Behaviour Disorders of Children and Youth, Toronto: Merril Publishing Company Columbus London.

Lundman, J. Richard, 1993, Prevention and Control of Juvenile Deliquency, Oxford: Oxford University Press.

Nasrhiana, 2012. Perlindungan Hukum Pidana bagi Anak Indonesia, Jakarta: Rajawali Pers.

Sambas, N., 2013. Peradilan Pidana Anak di Indonesia dan Instrumen Internasional Perlindungan Anak serta Penerpannya, Yogyakarta: Graha Ilmu.

Sarwono, Sarlito Wirawan, 2012. Psikologi Remaja, Jakarta: Rajagrafindo Persada.

Soetodjo, Wagiati, 2008, Hukum Pidana Anak, Bandung: Refika Aditama.

\section{Undang-Undang}

- Undang-undang Nomor. 23 Tahun 2003, tetang Perlindungan anak.

- Undang-Undang Nomor 35 tahun $2014 \quad$ Tentang Perlindungan Anak.

- Undang-Undang Nomor 11 Tahun 2012 Tentang Sistem Peradilan Pidana Anak. 